Elżbieta Jadwiga Biesaga-Stomczewska

\title{
Komunikacja wewnętrzna $w$ procesie porozumiewania się pracodawcy z pracownikami
}

\section{Wstęp}

Złożoność i zmienność otoczenia, w którym przyszło funkcjonować współczesnym przedsiębiorstwom, spowodowały konieczność przyjęcia nowej perspektywy patrzenia na zarządzanie ludźmi, zwłaszcza w kwestii przywództwa, otwartości i przyjaznego traktowania podwładnych oraz budowania satysfakcjonujących relacji. Niewątpliwie rynek pracodawcy i istniejący stan bezrobocia spowalnia proces zmian w postawach pracodawców względem swoich pracowników. Podobnie pracownicy, wobec braku stabilności zatrudnienia, niemożności znalezienia pracy odpowiadającej ich oczekiwaniom, nie są skłonni do postaw lojalnościowych względem firmy, do pełnego uruchamiania posiadanych zasobów wiedzy i umiejętności czy angażowania się w realizację wyznaczonych przez pracodawcę zadań.

Dodatkowym problemem wewnątrzorganizacyjnym XXI wieku, z którym muszą zmierzyć się pracodawcy, jest różnorodność pokoleniowa pracowników. Dążenie do zapewnienia poprawnych relacji wewnętrznych niestety nie zawsze uwzględnia cechy różnicujące poszczególne pokolenia. Wprawdzie zarządzający firmą coraz więcej czasu i uwagi poświęcają poznaniu i zrozumieniu potrzeb swoich podwładnych, to jednak nie przekłada się to na chęć rozpoznania odmienności wynikających z różnic pokoleniowych, co zmniejsza w znacznym stopniu skuteczność stosowanych narzędzi motywacyjnych oraz spowalnia proces budowania relacji partnerskich między osobami o różnych osobowościach, postawach i wyznawanych wartościach. Dotyczy to zwłaszcza pracowników nowej generacji Y, dla których praca zawodowa nie stanowi o sensie życia, a traktowana jest jedynie jako źródło dochodów ${ }^{1}$.

${ }^{1}$ E. Rudawska, Rola i techniki marketingu wewnętrznego $w$ ksztaltowaniu relacji z klientami instytucjonalnymi, [w:] Marketing relacji na rynku business to business, red. M. Mitręga, Wyd. Akademii Ekonomicznej w Katowicach, Katowice 2007, s. 69-83. 
Możliwość lepszego rozpoznania wzajemnych potrzeb i oczekiwań daje implementowanie założeń marketingu wewnętrznego, opierającego się w głównej mierze na komunikacji dającej podstawę do integrowania działań wewnętrznych w przedsiębiorstwie poprzez koordynowanie wszelkich kontaktów między zarządzającymi i pracownikami w ramach funkcji przewodzenia, z uwzględnieniem narzędzi, kanałów i barier komunikacji oraz satysfakcji jej adresatów ${ }^{2}$. Niestety, nie zawsze komunikowanie oznacza porozumienie się stron. Jak słusznie zauważa J.C. Maxwell „wszyscy rozmawiają i wszyscy się komunikują, lecz niewielu potrafi się porozumiewać. Ci, którym się to udaje, osiągają w relacjach z innymi, w pracy i życiu zupełnie nowy poziom"3.

Stwierdzenie to stało się inspiracją do nakreślenia celu opracowania, którym jest zaprezentowanie roli komunikacji wewnętrznej w procesie porozumiewania się pracodawcy z pracownikami w obszarze funkcji personalnej (zwłaszcza w procesie rekrutacji, selekcji czy motywowania), postrzeganej z perspektywy koncepcji zarządzania zasobami ludzkimi i marketingu wewnętrznego.

Podstawę źródłową opracowania stanowią studia literaturowe, wyniki badań różnych ośrodków naukowo-badawczych oraz obserwacje i przemyślenia autorki.

\section{Komunikacja wewnętrzna z perspektywy marketingu wewnętrznego i zarządzania zasobami ludzkimi}

Komunikacja należy do instrumentarium marketingu wewnętrznego, często utożsamianego z narzędziami, które wykorzystuje się w zarządzaniu zasobami ludzkimi. Różnice między narzędziami wydawać się mogą iluzoryczne, co wynika z faktu dokonywania porównań bez należytego odnoszenia się do istoty obu koncepcji.

Niezależnie od lansowanej koncepcji komunikacja ogrywa niekwestionowaną rolę w integrowaniu pracowników wokół strategii firmy, poprzez przekaz informacji oraz znaczeń, w wyniku którego dochodzi do formalnych i nieformalnych interakcji, a tym samym scalania wszystkich działań przedsiębiorstwa ${ }^{4}$. Prawidłowo funkcjonujący system komunikacji wewnętrznej zaspokaja potrzebę przyna-

${ }^{2}$ A. Olsztyńska, Marketing wewnętrzny w przedsiębiorstwie. Koncepcja i narzędzia wspomagające integrację działań wewnętrznych w organizacji, Wyd. Akademii Ekonomicznej w Poznaniu, Poznań 2005, s. 17-18.

3 J.C. Maxwell, Wszyscy się komunikuja, niewielu potrafi się porozumieć, MT Biznes, Warszawa 2011, s. 12.

${ }^{4}$ E.J. Biesaga-Słomczewska, Negocjacje jako narzędzie zarządzania $w$ organizacji zorientowanej na rynek, Wyd. Uniwersytetu Łódzkiego, Łódź 2009, s. 200. 
leżności do danej społeczności organizacyjnej, wyzwalając poczucie uczestnictwa w życiu firmy. Staje się zatem instrumentem tworzenia relacji, co przekłada się na scalanie wspólnoty ${ }^{5}$.

Zaprezentowane rozumienie komunikacji jako instrumentu zarządczego oraz uważna analiza treści literaturowych z zakresu zarządzania ludźmi i marketingu wewnętrznego pozwala na uchwycenie subtelnych różnic, jakie występują w nakreślaniu roli komunikacji w wymienionych koncepcjach. Podstawowa różnica tkwi w definiowaniu istoty komunikacji. W zarządzaniu zasobami ludzkimi proces komunikacji oceniany jest głównie z perspektywy mechanicznej (zbieranie i przepływ informacji), natomiast w marketingu wewnętrznym akcentowany jest nie tylko przepływ informacji, ale też różne zależności wynikające z:

- kontekstu struktury organizacyjnej (np. układ zależności między stanowiskami wymuszający komunikację formalną);

- cech osobowościowych adresata (każdy ma inną percepcję, inaczej odbiera informacje itp.);

- symboliki i znaczeń (każda organizacja ma swój system symboli i znaczeń pozwalający na wspólną interpretację wydarzeń wewnętrznych) ${ }^{6}$.

Różnice w podejściu do komunikacji dostrzega się zwłaszcza w takich obszarach funkcji personalnej, jak nabór (rekrutacja) i dobór (selekcja) pracowników oraz ich motywowanie. Warto zasygnalizować zwłaszcza te, które w sposób znaczący różnią obie koncepcje.

\section{Tradycyjne i marketingowe podejście do komunikacji wewnętrznej w procesie naboru i doboru pracowników}

Nabór (rekrutacja) pracowników do firmy funkcjonującej zgodnie z założeniami koncepcji ZZL polega na poszukiwaniu kandydata na stanowisko pracy według przyjętych procedur. Komunikacja z kandydatem ma przebieg sformalizowany, ograniczony gorsetem obowiązujących przepisów i zarządzeń wewnętrznych. Trudno jest doszukać się w tym procesie elementów humanizacji pracy, przejawiających się chociażby w zbieraniu informacji o psychofizycznych potrzebach kandydata. Potencjalni pracodawcy nie widzą też potrzeby poznania jego ewentualnych preferencji odnośnie do pracy na danym stanowisku (np. dotyczących zakresu obowiązków, czasu pracy, obowiązujących procedur). Brak dialogu

${ }^{5}$ G. Rosa, Komunikacja i negocjacje w biznesie, Wyd. Nauk. Uniwersytetu Szczecińskiego, Szczecin 2009

${ }^{6}$ A. Olsztyńska, op. cit., s. 40. 
i jednowymiarowość komunikacji powodują, że proces rekrutacji, uwzględniający tylko oczekiwania pracodawcy, przybiera postać bezosobowych formuł. Potencjalny pracownik jest postrzegany głównie przez pryzmat stanowiska pracy i przysługującego mu uposażenia, co przekreśla możliwość zbudowania więzi innych niż ekonomiczne. Pracodawca nieuwzględniający potrzeb pracownika w zakresie współuczestniczenia w ,życiu firmy” i bycia częścią zbiorowości, stwarza sytuację, która powoduje jego dystansowanie się zarówno pod względem fizycznym, jak i emocjonalnym ${ }^{7}$, chociaż nadal jest wielu menedżerów, którzy przykładają zbyt dużą wagę do swojego intelektu wierząc, że „wystarczy komunikować się przedstawiając logiczne rozumowanie, by przekonać ludzi do jakiejś koncepcji”.

Budowanie poprzez komunikację więzi między pracodawcą a pracownikiem ma swój początek już na etapie rekrutacji. Rekruterzy rzadko jednak przywiązują wagę do faktu, że przesyłane komunikaty muszą uwzględniać elementy emocjonalne, gdyż to właśnie one stwarzają przyjazny klimat rozmowy. Zapominają, że rodząca się więź, niemająca oparcia w emocjach i uczuciach, jest postrzegana jedynie w wymiarze transakcyjnym i ma charakter tymczasowy ${ }^{9}$. Prędzej czy później obie strony, nie wytworzywszy obopólnie satysfakcjonujących relacji, będą dążyły do zmiany zaistniałego stanu (pracodawca przy nadarzającej się okazji zwolni pracownika, ten z kolei zacznie rozważać przejście do innej firmy).

Zupełnie inną wagę przykłada się do komunikacji przy rekrutacji dokonywanej w myśl założeń marketingu wewnętrznego. Wszystkie działania w ramach naboru pracowników opierają się tu na komunikacji traktowanej w kategoriach dwukierunkowego przepływu informacji między pracodawcą i pracownikiem. Treść dwustronnie przesyłanych komunikatów dotyczy oczekiwań stron odnośnie do pełnionych funkcji, zakresu obowiązków i możliwości wywiązywania się z nich zgodnie z interesem firmy, czasu pracy, wynagrodzenia, ścieżek rozwoju indywidualnego, sposobów podejmowania decyzji itp. Nie jest przy tym zaniedbywany aspekt emocjonalny komunikacji. Uczucie stanu zadowolenia pracownika jest efektem dokonywanej przez obie strony kalkulacji zysków i strat. Podstawą porównań są głównie wartości niematerialne, takie jak prestiż, proponowane stanowisko w firmie, możliwość samorealizacji, awans itp., za które pracownik rewanżuje się takimi wartościami, jak lojalność, zaangażowanie w realizację zadań wyznaczonych przez firmę, otwartość na zmiany, chęć podnoszenia kwalifikacji. W tym sensie idea marketingu wewnętrznego nawiązuje do koncepcji gry spo-

\footnotetext{
7 J.C. Maxwell, op. cit., s. 37.

8 Ibidem, s. 75.

9 A.J. Baruk, Marketing personalny a kreowanie wizerunku firmy, Akademia Rolnicza, Lublin 2005, s. 23.
} 
łecznej i Crozierowskiej wizji organizacji, utożsamianej z szeroko rozumianym systemem społecznym, systemem stosunków wewnętrznych i zewnętrznych ${ }^{10}$. Każdy członek organizacji aktywnie uczestniczy w grze społecznej z zamiarem zrealizowania swoich interesów. Istota tej gry polega na tym, że każdy działa według kalkulacji własnych interesów. Każdy dąży do maksymalizacji własnych korzyści. Chcąc jednak otrzymać określone wartości od innych, musi zapłacić określonym wkładem własnym. Oznacza to, że każdy w organizacji, dążąc do osiągnięcia własnych celów, musi uwzględnić cele drugiej strony. By się w tym przedmiocie porozumieć strony muszą wzajemnie komunikować swoje potrzeby i oczekiwania. Ten swoisty rodzaj toczącej się gry zmienia sposób postrzegania pracownika - z perspektywy „stanowiska pracy” (jak to dzieje się w przypadku ZZL) na perspektywę „roli organizacyjnej”, którą odgrywa w firmie ${ }^{11}$.

Komunikacja jest również podstawą działań w obszarze doboru (selekcji) pracowników. Niestety, w koncepcji ZZL komunikacja przybiera głównie wymiar formalny i ustrukturyzowany. Przydatność kandydata do pracy jest weryfikowana według ustalonych kryteriów (wykształcenie, doświadczenie, wiek itp.), często uzupełnianych testami kompetencyjnymi. Nieprzywiązywanie wagi do komunikacji dwustronnej rodzi stan zagubienia kandydata, który nie rozumiejąc przyczyn ewentualnej eliminacji, czuje się rozczarowany i niedoceniony. Brak znajomości faktów, które dla drugiej strony mogą być ważne, czy też niebranie pod uwagę jej punktu widzenia, wynika z braku dialogu i chęci poznania wzajemnych oczekiwań.

Często przyczyną pojawiających się frustracji jest nieumiejętność porozumiewania się na poziomie emocjonalnym. Tymczasem słowa są niekiedy „o wiele mniej ważne od energii, intensywności i przekonania, z jakimi są wypowiadane. Ludzie słyszą wypowiadane przez ciebie słowa, lecz wyczuwają też twoje nastawienie, nie zawsze będą pamiętali, co powiedziałeś lub zrobiłeś. Zapamiętają jednak na zawsze, jakie uczucia w nich wzbudziłeś"12.

Zupełnie inną rolę przypisuje się komunikacji w procesie ostatecznego doboru (selekcji) przebiegającego zgodnie z założeniami marketingu wewnętrznego. Podstawą tego procesu jest nie tylko jednostronne weryfikowanie kompetencji pracownika pod kątem jego przydatności na danym stanowisku pracy, ale dialog, w którego wyniku strony wymieniają informacje na temat warunków „wejścia” do firmy, możliwości samookreślenia się kandydata, podejścia do zaangażowania się w proces generowania wiedzy, usprawniania własnych działań itp. Taka

${ }^{10}$ M. Crozier, Przedsiębiorstwo na podstuchu. Jak uczyć się zarządzania postindustrialnego, PWE, Warszawa 1993, s. 42.

${ }^{11}$ E.J. Biesaga-Słomczewska, op. cit., s. 202.

12 J.C. Maxwell, op. cit., s. 76. 
dwustronna komunikacja na etapie prowadzonej przez firmę rekrutacji i selekcji jest w pełni uzasadniona, gdyż każdy pracownik ma określone predyspozycje do wykonywania danej pracy, jest uwikłany w różne sprawy rodzinne, inaczej rozumie własną rolę w strukturze organizacyjnej. Rozwijanie komunikacji opartej na zaufaniu i szczerości wpływa na wspólne zrozumienie obopólnych oczekiwań i pobudza do dyskusji nad możliwością zmian. Niedocenianie skuteczności takiej formy komunikacji należy traktować w kategorii błędu zarządczego, którego konsekwencją jest niezadowolenie pracodawcy i frustracja pracowników.

Komunikacja odgrywa również niezmiernie istotną rolę w toczących się w firmach procesach derekrutacyjnych. Prowadzenie działań wspomagających zwolnionych pracowników (outplacement), przybierające różne formy pomocy zarówno finansowej (otrzymanie odprawy), jak i w zakresie odnalezienia się na rynku pracy (propozycja szkoleń, pomoc firm doradczych, zaproponowanie pracy w innej firmie itp.) musi się jednak opierać na rzetelnej analizie ich oczekiwań. Niestety, z toczących się na łamach literatury dyskusji ${ }^{13}$ można wnioskować, że nie zawsze zachodzi komunikacja oparta na dialogu między zwalnianym pracownikiem a pracodawcą, przez co działania firm, nie będąc w stanie rozpoznać specyfiki rzeczywistych potrzeb i oczekiwań osoby derekrutowanej - oferują jej „cokolwiek”. Stąd też większość poczynań outplacementowych należy uznać za przestarzałe, mające charakter pozornej troski zamiast faktycznej pomocy, jaka zwłaszcza jest potrzebna osobom w wieku powyżej 45 lat, tzw. BB (baby boomers) ${ }^{14}$, które straciły pracę, mało orientują się w realiach rynku pracy, są zagubione i źle odbierają status bezrobotnego. Niestety, wskaźnik zatrudnienia osób powyżej 50. roku życia należy do najniższych w Unii Europejskiej ${ }^{15}$.

\section{Motywacyjny charakter komunikacji wewnętrznej}

Komunikacja odgrywa również olbrzymią rolę w obszarze motywacyjnym. Przybierając określoną formę może przyczynić się do ukształtowania motywującego bądź demotywującego dla pracowników środowiska pracy. Obserwacja praktyk stosowanych w wielu firmach dostarcza przykładów świadczących o tym, że stosowane są głównie tradycyjne formy komunikacji między pracodawcą a pracownikiem, opierające się na sformalizowanych systemach określających

13 J. Woźniak, Współczesne systemy motywacyjne, Wyd. Nauk. PWN, Warszawa 2012, s. $195-201$.

${ }^{14} \mathrm{~S}$. Popiel, Generacje a rekrutacje. Jak różnice pokoleniowe wpływają na strategię zatrudnienia, „Personel i Zarządzanie” 2013, nr 1, s. 75.

15 J. Spisacka, Żadna posada nie jest na zawsze, „Newsweek Polska” 2013, nr 35, s. 76-77. 
wymagania $\mathrm{w}$ zakresie przyjętych procedur działania, przestrzegania regulaminów, strategii firmy, celów i wynikających z nich określonych zadań. Ich celem jest wywieranie wpływu na pracowników, często poprzez straszenie określonymi karami (utrata premii, a nawet pracy), by wywołać w adresatach gotowość do podporządkowania się formalnym procedurom. Oczywiście należy mieć świadomość konieczności istnienia wielu $\mathrm{z}$ wymienionych form komunikowania się z pracownikami, chociażby poprzez regulaminy czy przepisy wynikające z warunków pracy. Problem pojawia się jednak wtedy, gdy pracodawcy starają się narzucić pewne rozwiązania odnoszące się do narzędzi czy technologii pracy wszystkim pracownikom, niezależnie od specyfiki czynników kształtujących możliwość skutecznego działania na danym stanowisku pracy. Stosowanie zunifikowanych rozwiązań, dostosowanych do przeciętnych potrzeb typowego pracownika, staje się źródłem wielu nieporozumień i problemów, co w efekcie prowadzi do wyzwalania u pracowników poczucia niepewności, a nawet bezsilności. Ten, często opisywany w podręcznikach ${ }^{16}$, nadmiernie sformalizowany charakter komunikacji, przyjmujący głównie postać przekazywania poleceń, jest charakterystyczny dla tradycyjnego zarządzania zasobami ludzkimi.

Motywacyjny charakter komunikacji między pracodawcą a pracownikami, co szczególnie jest akcentowane w założeniach koncepcji marketingu wewnętrznego, występuje wtedy, gdy uwzględnia się indywidualne podejście do pracowników, będące odpowiedzią na ich zróżnicowane potrzeby i oczekiwania. Uznanie przez pracodawcę zróżnicowania potrzeb i w konsekwencji tego zastosowania indywidualnych rozwiązań swobodnie kształtujących środowisko pracy, jest ważnym czynnikiem „sprzyjającym rozpowszechnieniu się przyciągania talentów" ${ }^{17}$ oraz pełnego wykorzystywania potencjału już zatrudnionych pracowników.

Akcentowanie wagi dwustronnej komunikacji opartej na dialogu sprzyja rozpoznawaniu potrzeb i oczekiwań, co pozwala traktować ją jako swego rodzaju proces wpływu wzajemnego. Koncentrowanie się na treściach komunikatu, wsłuchiwanie się w intencje nadawcy, skupianie się na problemie czy unikanie przypisywania rozmówcy negatywnych intencji tworzy fundament porozumiewania się. Przejrzystość i jednoznaczność treści komunikatów, zwłaszcza na linii pracodawcapracownik, zwiększa szansę na współuczestniczenie w procesach zachodzących w przestrzeni organizacyjnej ${ }^{18}$ i zbudowanie więzi partnerskich ${ }^{19}$.

16 A. Pocztowski, Zarzadzanie zasobami ludzkimi, PWE, Warszawa 2007; R. Walkowiak, Zarzadzanie zasobami ludzkimi: kompetencje, nowe trendy, efektywność, Wydawnictwo TNO i K, Toruń 2007

${ }^{17}$ J. Woźniak, op. cit., s. 141.

${ }^{18}$ Ch. Woodruffe, Employee Engagement- The Real Secret of Winning a Crucial Edge over your rivals, „Manager Motivation” 2006, December-January.

19 W.H. Macey, B. Schneider, The Meaning of Employee Engagement, „Industrial and Organizational Psychology" 2008, vol. 1, s. 15. 
Spojrzenie na system komunikacji wewnętrznej przez pryzmat zaspokajania obopólnych oczekiwań, tj. pracowników i pracodawcy, określa kierunek i formę przepływu komunikatów, które płyną nie tylko z góry do dołu, ale również z dołu do góry, czyli od pracowników do zarządzających. P. Drucker ${ }^{20}$ uważa właśnie ten kierunek przepływu informacji za bardzo istotny dla sprawnego funkcjonowania nowoczesnego przedsiębiorstwa. Głównym źródłem informacji na temat potrzeb i oczekiwań pracowników są zazwyczaj skrzynki pomysłów i problemów, skrzynki zażaleń, zebrania, briefingi, intranet, ale również różne niestandaryzowane formy zbierania indywidualnych opinii od pracowników.

Dużą rolę w rozpoznawaniu wzajemnych oczekiwań odgrywa komunikacja nieformalna, odbywająca się podczas nieoficjalnych spotkań po pracy, imprez integracyjnych itp. Często też przybiera ona postać kontrolowanych plotek i pogłosek rozchodzących się w przestrzeni organizacyjnej we wszystkich kierunkach, tj. w górę, w dół, poziomo - za pomocą przekazu słownego lub poprzez teleinformatyczne środki komunikacji. Skutecznym narzędziem komunikacji nieformalnej okazuje się również management by walking around (MBWA), który polega na nieformalnych rozmowach kadry zarządzającej z pracownikami poza biurem. Ta forma zbierania informacji o oczekiwaniach pracowników jest, jak dotychczas, bardzo skuteczna. Wykazywanie zainteresowania zarządzających problemami pracowników odbierane jest jako wyraz troski o ich losy i chęć poprawy środowiska pracy, co sprzyja przekazywaniu spostrzeżeń i krytycznych uwag, których nie zakomunikowaliby formalnie. Taka forma komunikowania się z pracodawcą motywuje pracowników do otwartości i kreatywności, gdyż dostrzegają oni szansę na wykorzystanie ich uwag do poprawy funkcjonowania przedsiębiorstwa. Mając na uwadze własny interes dają jasne sygnały dotyczące pożądanych przez siebie wartości ${ }^{21}$.

Nadal jednak niedocenianym sposobem wymiany informacji płynących z dołu do góry jest system konsultowania, który może przyjąć w niektórych przypadkach nawet wymiar negocjacyjny - „coś za coś”. Taka forma wzajemnego rozpoznawania potrzeb i oczekiwań wydaje się szczególnie wskazana, chociażby przy ustalaniu kryteriów przyznawania premii, nagród czy też dodatkowego nagradzania pracowników, przykładowo za ich wkład w usprawnianie działań jednostki operacyjnej, podnoszenie efektywności pracy, współtworzenie procedur, wspólne diagnozowanie problemów, pracę w godzinach ponadnormatywnych, otwartość i społeczne zaangażowanie.

Niewątpliwie niedocenianą formą motywowania przez wykorzystanie komunikacji jest walka ze stresem w pracy. Każdy podmiot działający w przedsiębior-

${ }^{20}$ P. Drucker, Menedżer skuteczny, Wyd. Akademii Ekonomicznej, Kraków 1994, s. 79.

${ }^{21}$ A. Olsztyńska, op. cit., s. 45-46. 
stwie, czyli pracodawcy, zarządzający w ich imieniu kierownicy, menedżerowie, jak również podlegający im pracownicy funkcjonują pod wpływem stresu, jaki powstaje na tle różnych wydarzeń, które napotykają niemal w każdej sferze swojej aktywności zawodowej. Raport przygotowany przez Europejską Fundację na rzecz Poprawy Warunków Życia i Pracy, opublikowany w 2001 roku $^{22}$ wskazuje na następujące najczęściej występujące przyczyny stresu związanego z pracą:

- poczucie braku kontroli nad kolejnością wykonywania swoich zadań, możliwością zrobienia przerwy w pracy, wyborem metody i tempa pracy itp.,

- monotonia pracy,

- naglące terminy,

- szybkie tempo pracy.

Oczywiste jest, że czynników powodujących stres w środowisku i procesie pracy jest dużo więcej, a natężenie ich oddziaływania na pracowników zależy od wieku osoby, jej pozycji w firmie, stopnia jej wrażliwości, własnej samooceny itp. Najczęściej jednak stres w miejscu pracy pojawia się u człowieka w wyniku nałożenia się dwóch czynników: stopnia kontroli, jaką sprawuje nad swoją pracą oraz wymagań, jakie narzuca miejsce pracy ${ }^{23}$ (m.in. w zakresie wspomnianej już swobody działania jednostki odnośnie do wyboru terminu, tempa pracy czy sposobu realizowania powierzonych jej zadań). Oto przykłady:

- zgodnie z obowiązującym systemem motywacyjnym pracownik zostaje „ukarany” utratą kilku procent przysługującej mu premii, jeśli nie będzie uczestniczył w okresowym zebraniu - nawet wówczas, gdy w tym samym czasie wypadną mu inne ważne sprawy związane z firmą;

- zgodnie z dyrektywnie obowiązującymi przepisami dotyczącymi wystawiania ocen studentom, prowadzący zajęcia jest zobowiązany już na początku semestru ustalić i podać do wiadomości zainteresowanym bardzo szczegółowe kryteria zaliczenia, np. rodzaj pytań, jaki będzie zawierał planowany test (otwarte czy zamknięte, czy będzie jednokrotnego, czy może wielokrotnego wyboru) - choć dydaktyk nie wie jeszcze, jaki poziom wiedzy „na wejściu” reprezentują wszyscy studenci, z którymi przyjdzie mu współpracować, jaka będzie ich percepcja itp. Trudno mu też ustalić z góry, ile punktów przydzieli za dobrą odpowiedź, a o ile obniży ocenę za złą, bez określenia skali trudności pytania czy jego rangi.

Trudno się więc dziwić, że nadmierna standaryzacja w wielu przypadkach zamiast ułatwiać pracę - utrudnia jej wykonanie. Rodzi to frustrację i zniechęcenie, zwłaszcza u doświadczonych pracowników, którzy bazując na posiadanej wiedzy

${ }^{22}$ E. Beck, A. Orlińska-Gondor, Stres jako kategoria jednostkowa i organizacyjna, [w:] Nowe tendencje $i$ wyzwania w zarządzaniu personelem, red. L. Zbiegień-Maciąg, Oficyna Ekonomiczna, Kraków 2006, s. 247.

${ }^{23}$ J. Woźniak, op. cit., s. 145. 
i zasobach doświadczeń, często krytycznie podchodzą do proponowanych nowych rozwiązań w zakresie wykonywanej od lat pracy i nie widzą sensu wprowadzania sztywnych ram. Narzucenie standaryzowanego systemu oceniania dla wszystkich pracowników według ustalonych kryteriów, bez uwzględnienia stopnia trudności powierzanych im zadań, ponoszonej odpowiedzialności, wagi popełnionego błędu czy rangi problemu i umiejętności radzenia sobie z nim, jest odbierane jako „zamach" na ideę personifikacji, tak mocno akcentowaną w koncepcji marketingu wewnętrznego. Dlatego też forma komunikacji oparta na relacji władzy w przypadku doświadczonych pracowników powinna zostać zawieszona, gdyż traci ona swą motywacyjną moc. Stosowanie dyrektywnych form komunikowania się pracodawcy z pracownikiem jest $\mathrm{w}$ pewnym zakresie uzasadnione $\mathrm{w}$ przypadku młodych i jeszcze niedoświadczonych osób, które dzięki narzuconym wzorcom mogą działać niejako mechanicznie i wykonywać powierzone im zadania bez konieczności głębszego analizowania występującego przypadku. Zmniejsza się tym samym wystąpienie zagrożenia stresem i ogranicza się negatywne konsekwencje zdrowotne, wszystkie bowiem działania są regulowane przez utworzony gorset wystandaryzowanych nakazów i zakazów. Niestety, nie należy zapominać o tym, że tworzenie ,ram” hamuje kreatywność pracownika, jego wrażliwość, zmniejsza też możliwości rozwoju nowych umiejętności ${ }^{24}$.

Warto wspomnieć również o wykorzystywanych w zarządzaniu zasobami ludzkimi formach komunikacji formalnej przybierającej postać procedur dyrektywnego nadzorowania samodzielności pracy młodego pracownika, o charakterze instruktorskim ${ }^{25}$. Niewątpliwie dostarczają one informacji o przystosowaniu się pracownika do określonego stanowiska pracy, o posiadanych przez niego umiejętnościach. Żeby jednak ta forma komunikacji spełniała swoją funkcję motywacyjną, zwłaszcza przy doskonaleniu wyższej kadry pracowniczej, powinna być oparta na tzw. coachingu niedyrektywnym, zwanym też psychologicznym ${ }^{26}$, czyli dwustronnej komunikacji dostarczającej informacji na temat potrzeb i oczekiwań pracownika czy odczuwanych przez niego trudności. Uzupełniona komunikacją nieformalną pozwala na uzyskanie szerszych informacji niezbędnych do nakreślenia faktycznego profilu kompetencyjnego pracownika i odkrycia jego nieujawnionego jeszcze potencjału.

Firmy wdrażające ideę marketingu wewnętrznego wyznaczają olbrzymią rolę komunikacji nieformalnej, traktując ją jako jeden ze sposobów wspierających proces humanizacji pracy. Można też do nich zaliczyć stosowanie tzw. otwartej prze-

${ }^{24}$ Ibidem, s. 148-151.

${ }_{25}$ A. Sitko-Lutek, Kulturowe uwarunkowania doskonalenia menedżerów, UMCS, Lublin 2005, s. 108.

26 B. Peltier, Psychologia coachingu kadry menedżerskiej, Rebis, Poznań 2005. 
strzeni biurowej (open space), umożliwiającej szybką i bezpośrednią komunikację (poprzez kontakt wzrokowy i głosowy) między pracownikami oraz przełożonym, czy „otwartych drzwi szefa”, które sygnalizują jego dostępność dla współpracowników. Należy to potraktować jako symboliczny znak „bezpośredniości kultury komunikacyjnej w organizacji, który podkreśla wysoką rangę, jaką przywiązuje się w danej organizacji do bezpośredniej komunikacji ze współpracownikami”"27. Tak zmodyfikowaną przestrzeń organizacyjną należy niewątpliwie odczytywać jako jednoznaczny komunikat dla każdego pracownika, że firma traktuje go jako członka zespołu. Niesie to również przesłanie, że współcześnie działające organizacje dążą do zlikwidowania barier komunikacyjnych między pracodawcą a pracownikiem.

\section{Zakończenie}

Tradycyjny sposób pojmowania komunikacji wewnętrznej i postrzegania jej w kategoriach prostego przepływu informacji, bez uwzględniania skomplikowanych zależności wewnątrzorganizacyjnych, wpływu czynnika ludzkiego oraz jej aspektów symbolicznych (takich jak język czy kody niewerbalne) powoli traci na aktualności. Jej formalny wymiar wynikający z przypisywania rangi hierarchicznemu podporządkowaniu, nadaje komunikacji charakter statyczny, nieadekwatny do wymogów funkcjonowania nowoczesnego przedsiębiorstwa. Dyscyplinowanie ludzi poprzez tworzenie sztywnych procedur i procesów osłabia zaangażowanie pracowników i poczucie wspólnoty oraz hamuje ich kreatywność.

Komunikacja nie jest tylko procesem wymiany informacji. Każda informacja może być różnie interpretowana, np. w zależności od narzędzia komunikacji czy kontekstu organizacyjnego. Należy ją też zawsze rozpatrywać w wymiarze relacyjnym (zwracającym uwagę na zaangażowanie podmiotów, chęć tworzenia więzi, szukania płaszczyzny porozumienia i jednoczenia się wokół wspólnej idei), emocjonalnym (wynikającym z cech osobowościowych) czy też etycznym (manipulacja).

Nadanie nowej roli komunikacji wewnętrznej, akcentowane w założeniach koncepcji marketingu wewnętrznego, wychodzi naprzeciw współczesnym wyzwaniom, przed którymi stoją pracodawcy chcący podnosić jakość zarządzania czynnikiem ludzkim poprzez budowanie atmosfery pracy opartej na zaufaniu i więziach partnerskich, poprzez motywowanie uwzględniające oczekiwania pracowników czy poprzez ich włączanie w procesy decyzyjne. „Ludzie mają po-

27 J. Woźniak, op. cit., s. 161. 
trzebę współuczestnictwa i bycia częścią zbiorowości"28 trzeba tylko stworzyć ku temu odpowiednie warunki.

Nowe spojrzenie na komunikację wewnętrzną należy traktować jako milowy krok w kierunku humanizacji pracy, przejawiającej się nie tylko w dążeniu do dostosowania pracy do psychofizycznych możliwości oraz potrzeb określonego człowieka, ale również $\mathrm{w}$ docenieniu jego roli w procesie tworzenia wartości przedsiębiorstwa. Zarządzając ludźmi należy więc zawsze pamiętać, że „porozumienie zaczyna się w momencie, gdy druga strona wie, że jest ceniona"29.

\section{Bibliografia}

Baruk A.J., Marketing personalny a kreowanie wizerunku firmy, Akademia Rolnicza, Lublin 2005

Beck E., Orlińska-Gondor A., Stres jako kategoria jednostkowa i organizacyjna, [w:] Nowe tendencje i wyzwania w zarządzaniu personelem, red. L. Zbiegień-Maciąg, Oficyna Ekonomiczna, Kraków 2006

Biesaga-Słomczewska E.J., Negocjacje jako narzędzie zarządzania w organizacji zorientowanej na rynek, Wyd. Uniwersytetu Łódzkiego, Łódź 2009

Crozier M., Przedsiębiorstwo na podsłuchu. Jak uczyć się zarządzania postindustrialnego. PWE, Warszawa 1993

Drucker P., Menedżer skuteczny, Wyd. Akademii Ekonomicznej, Kraków 1994

Macey W.H., Schneider B., The Meaning of Employee Engagement, „Industrial and Organizational Psychology" 2008, vol. 1

Maxwell J.C., Wszyscy się komunikuja, niewielu potrafi się porozumieć, MT Biznes, Warszawa 2011

Olsztyńska A., Marketing wewnętrzny w przedsiębiorstwie. Koncepcja i narzędzia wspomagajace integrację działań wewnętrznych w organizacji, Wyd. Akademia Ekonomiczna w Poznaniu, Poznań 2005

Peltier B., Psychologia coachingu kadry menedżerskiej, Rebis, Poznań 2005

Pocztowski A., Zarzadzanie zasobami ludzkimi, PWE, Warszawa 2007

Popiel S., Generacje a rekrutacje. Jak różnice pokoleniowe wptywają na strategię zatrudnienia, „Personel i Zarządzanie” 2013, nr 1

Rosa G., Formy komunikacji Polaków na podstawie badań pokoleń Y, X i Baby Boomers, [w:] Problemy i przeobrażenia w zachowaniach współczesnych organizacji i konsumentów, „Zeszyty Naukowe Uniwersytetu Szczecińskiego” 2013, nr 751, Problemy Zarządzania, Finansów i Marketingu nr 29

28 J.C. Maxwell, op. cit., s. 23.

${ }^{29}$ Ibidem, s. 24. 
Rosa G., Komunikacja i negocjacje w biznesie, Wyd. Nauk. Uniwersytetu Szczecińskiego, Szczecin 2009

Rudawska E., Rola i techniki marketingu wewnętrznego w ksztaltowaniu relacji $z$ klientami instytucjonalnymi, [w:] Marketing relacji na rynku business to business, red. M. Mitręga, Wyd. Akademii Ekonomicznej w Katowicach, Katowice 2007

Sitko-Lutek A., Kulturowe uwarunkowania doskonalenia menedżerów, UMCS, Lublin 2005

Spisacka J., Żadna posada nie jest na zawsze, „Newsweek Polska” 2013, nr 35

Walkowiak R., Zarzadzanie zasobami ludzkimi: kompetencje, nowe trendy, efektywność, Wyd. TNO i K, Toruń 2007

Woodruffe Ch., Employee Engagement - The Real Secret of Winning a Crucial Edge over your rivals, „Manager Motivation” 2006, December-January

Woźniak J., Wspótczesne systemy motywacyjne, Wyd. Nauk. PWN, Warszawa 2012 